\title{
ANALISIS HUBUNGAN VARIABEL MONETER DI INDONESIA SEBELUM DAN SESUDAH PENERAPAN KEBIJAKAN INFLATION TARGETING FRAMEWORK \\ (ITF) PERIODE (1991.1-2010.4)
}

\author{
Dhaniar Aji Anggoro \\ Fakultas Ekonomi Universitas Airlangga
}

\begin{abstract}
ABSTRAK
Penelitian ini dilakukan untuk meneliti hubungan variabel moneter di Indonesia sebelum dan sesudah penerapan inflation targeting framework (ITF) yang terbagi dalam dua periode yaitu 1991.1-2000.4 dan 2001.1-2010.4. Tulisan ini secara khusus meneliti hubungan masing-masing variabel yaitu nilai tukar, tingkat suku bunga dan M2 terhadap inflasi pada kedua periode dengan menggunakan model vector error correction model (VECM), hasil dari penelitian ini menunjukkan bahwa adanya respon yang berbeda oleh inflasi terhadap masingmasing variabel sebelum dan sesudah penerapan ITF dimana respon terhadap nilai tukar cenderung positif sebelum penerapan ITF dan memiliki kontribusi shock yang besar berbeda dengan sesudah penerapan ITF dimana kontribusi shock terhadap inflasi jauh lebih kecil,sedangkan pada variabel tingkat suku bunga respon inflasi cenderung berfluktuasi sebelum penerapan ITF dan cenderung negatif setelah penerapan ITF dan kontribusi shock terhadap inflasi jauh lebih besar dibandingkan dengan variabel yang lain.

Kata kunci:Kebijakan Moneter Indonesia, Inflation Targeting Framework (ITF), Vector Error Correction Model (VECM),M2,Tingkat Suka Bunga, Nilai Tukar.
\end{abstract}

\section{PENDAHULUAN}

Kebijakan ekonomi terdiri dari kebijakan fiskal dan kebijakan moneter, dimana masing-masing kebijakan tersebut berusaha mencapai tujuan ekonomi di bidang yang berbeda, kebijakan fiskal merupakan kebijakan yang ditetapkan pemerintah menggunakan instrumen pajak dan pengeluaran pemerintah dalam mencapai kegiatan perekonomian yang diinginkan.

Dilain pihak kebijakan ekonomi yang digunakan dalam bidang keuangan adalah kebijakan moneter. Kebijakan moneter merupakan "kebijakan bank sentral dalam bentuk pengendalian besaran moneter untuk mencapai perkembangan kegiatan perekonomian yang diinginkan" (Warjiyo dan Solikin, 2004:2). Pengendalian besaran moneter antara lain jumlah uang beredar,uang primer,dan kredit perbankan memiliki tujuan yaitu menekan laju inflasi, peningkatan output riil, dan meningkatnya lapangan kerja sehingga mengurangi pengangguran.

Tekanan yang luar biasa terhadap nilai tukar dan cadangan devisa di awal krisis 1997 memaksa Bank Indonesia dan 
pemerintah melepas band intervensi dan menganut sistem nilai tukar mengambang bebas. Akibatnya nilai tukar tak lagi menjadi jangkar nominal kebijakan moneter. Depresiasi nilai rupiah yang teramat tajam dan suku bunga yang tinggi membuat sektor riil dan sektor perbankan semakin terpuruk. Perbankan kehilangan kepercayaan publik. Kegiatan usaha tidak bergerak produksi merosot dan jumlah pengangguran melonjak sehingga Indonesia mengalami krisis.

Krisis moneter yang terjadi di Indonesia sejak tahun 1997 memberi banyak pemikiran dan masalah yang mengakibatkan adanya banyak perubahan, salah satu diantaranya adalah perubahan dalam perumusan kebijakan ekonomi. Krisis ini telah menyebabkan penurunan kepercayaan masyarakat terhadap sektor perbankan sehingga terjadi penarikan dana besar-besaran oleh masyarakat dan menyebabkan kelangkaan dana pada sektor perbankan hal ini diperparah dengan semakin terdepresiasinya nilai tukar rupiah sehingga menguras cadangan devisa Indonesia.

Menghadapi tekanan yang begitu besar terhadap nilai tukar rupiah dan kebutuhan mengamankan cadangan devisa, maka pada tanggal 14 Agustus 1997 pemerintah Indonesia melakukan pergantian sistem nilai tukar yang dianut dari sistem nilai tukar mengambang terkendali menjadi sistem nilai tukar mengambang. Akan tetapi dibalik pergantian sistem nilai tukar ini, krisis mencapai puncaknya pada tahun 1998, dimana krisis yang bermula dari krisis moneter telah berubah cepat menjadi krisis ekonomi, krisis sosial, budaya, krisis politik, dan akhirnya menjadi krisis multidimensi.

Pemerintah terus melakukan upaya pemulihan kondisi di dalam negeri akibat krisis. Upaya pemerintah selanjutnya adalah memberlakukan Undang-Undang Nomor 23 Tahun 1999 Tentang Bank Indonesia (BI), dimana Bank Indonesia lebih independent dalam melaksanakan tugas dan tujuannya, dimana kebijakan moneter yang ditempuh oleh Bank Indonesia diarahkan untuk mencapai sasaran inflasi yang ditetapkan (inflation targeting).

Inflation targeting sebagai sebuah kerangka kebijakan moneter baru yang diharapkan dapat meningkatkan kredibilitas BI sebagai otoritas moneter, tetapi sejak dimulainya kerangka inflation targeting di Indonesia beberapa permasalahan mulai muncul yaitu tidak tercapainya tingkat inflasi yang dijadikan sebagai target dan juga peningkatan tingkat inflasi yang semakin meningkat. 
ITF juga berbeda dengan kebijakan moneter lain yang telah diterapkan sebelumnya. Dalam ITF yang diungkapkan adalah sasaran akhir (final target) yaitu inflasi, sedangkan pada kebijakan penargetan lainnya yang ditonjolkan adalah sasaran antara (intermediate target) yaitu jumlah uang beredar (money supply), nilai tukar (exchange rates) dan tingkat suku bunga (interest rate), oleh sebab itu ITF diharapkan dapat lebih baik daripada model-model lainnya karena memiliki tujuan utama yaitu tingkat inflasi yang rendah.

Svensson ( 1997), mengklaim bahwa rezim membantu dalam mengurangi variabilitas inflasi dan berpendapat bahwa jika rezim yang fleksibel, dapat membantu dalam menstabilkan Output juga.

\section{Bernanke , Laubach , Mishkin}

dan Posen ( 1999) menguraikan peran rezim IT sebagai kebijakan yang mempengaruhi ekspektasi inflasi masyarakat , mengklaim bahwa rezim menyediakan rencana eksplisit dan arah untuk pembuat kebijakan moneter. Hal ini pada akhirnya , membantu dalam menstabilkan inflasi

Neumann dan von Hagen ( 2002) berpendapat bahwa rezim IT membantu negara-negara dengan ekonomi rendah dapat mengejar ketinggalan, karena belajar dari penerapan kebijakan antar negara . Civcir dan AKC, aglayan ( 2010 ) menggunakan fungsi reaksi umum untuk Bank Sentral Republik Turki ( CBRT ) dan berpendapat bahwa penerapan rezim IT telah meningkatkan kredibilitas CBRT . hal ini dapat disimpulkan bahwa target Inflasi yang kredibel dapat menjadi jangkar dalam mempengaruhi ekspektasi inflasi.

Goncalves dan Salles ( 2008) menggunakan data untuk 36 negara berkembang ( yang 13 adalah IT ) selama periode 1980-2005 dan menunjukkan bahwa negara-negara IT mengalami pengendalian lebih besar dalam inflasi dan volatilitas tingkat pertumbuhan GDP . Hasil penelitian mereka menyiratkan bahwa rezim IT mungkin memiliki efek yang lebih signifikan terhadap kinerja ekonomi makro negara-negara berkembang dibandingkan yang tidak menerapkan.

Meskipun demikian, "tingkat inflasi yang rendah dan stabil masih menjadi kontroversi dan besarnya tingkat inflasi di setiap negara sulit untuk dikatakan sama"(Schmidt-Hebbel,2002).

Beberapa penelitian lain meragukan efektifitas penerapan inflation targeting dapat benar-benar berpengaruh terhadap tingkat penurunan inflasi salah satunya adalah penelitian Ball dan Sheridan (2005) menunjukkan bahwa 
tingkat inflasi juga menurun di negaranegara NT, serta negara-negara IT . Oleh karena itu, mereka menyimpulkan bahwa alasan untuk penurunan tingkat inflasi bukanlah penerapan rezim IT, tapi tergantung keadaan ekonomi.

Lin Ye ( 2007) berpendapat bahwa rezim IT tidak memiliki efek signifikan pada tingkat inflasi atau volatilitas . Sims (2005) menunjukkan bahwa rezim IT mungkin lebih berbahaya daripada bermanfaat, jika bank sentral tidak akan mampu mengendalikan jalur inflasi yang ditetapkan maka bank sentral akan kehilangan kredibilitas .

Hasil penelitian empiris tersebut menunjukkan bahwa masing-masing negara memiliki tingkat kestabilan inflasi yang berbeda oleh karena itu dibutuhkan suatu kredibilitas pada bank sentral masing-masing negara untuk menargetkan suatu tingkat inflasi yang sesuai dengan perekonomian, selain itu kredibilitas bank sentral dalam menjaga tingkat inflasi sesuai dengan target sangatlah penting karena hal ini akan mempengaruhi ekspektasi masyarakat di masa depan.

Berdasarkan penelitian-penelitian tersebut maka dapat dilihat bahwa variabel-variabel seperti jumlah uang beredar, nilai tukar dan suku bunga juga memiliki peran terhadap tingkat inflasi suatu negara dalam suatu transmisi kebijakan moneter oleh sebab itu dalam menjalankan kebijakan inflation targeting otoritas moneter perlu melihat seberapa besar variabel-variabel tersebut dalam mempengaruhi inflasi dan juga shock dari variabel-variabel tersebut dalam mempengaruhi tingkat inflasi sehingga otoritas moneter dapat menentukan target inflasi yang sesuai dengan perekonomian.

\section{KAJIAN PUSTAKA}

Kebijakan moneter di Indonesia dikontrol oleh Bank Indonesia sebagai otoritas moneter, kebijakan moneter yang digunakan oleh Bank Indonesia dalam mewujudkan stabilitas ekonomi makro terdiri dari kerangka strategis dan kerangka operasional.

Kerangka strategis umumnya terkait dengan pencapaian tujuan akhir kebijakan moneter (stabilitas harga, pertumbuhan ekonomi, dan perluasan kesempatan kerja) serta strategi untuk mencapainya (exchange Rate targeting, monetary targeting, Inflation targeting, implicit but not explicit anchor) (Warjiyo dan Solikin, 2004).

Kerangka operasional kebijakan moneter terdiri dari instrumen, sasaranoperasional, dan sasaran-antara yang digunakan untuk mencapai sasaran akhir. Sasaran-antara diperlukan karena adanya 
time lag antara pelaksanaan kebijakan moneter dengan hasil pencapaian sasaran akhir, sehingga untuk meninjau keefektifan suatu kebijakan, maka diperlukan adanya kebijakan yang dapat dilihat dengan segera (Pohan,2008:38).

Seperti yang tercantum dalam UU No.3 Tahun 2004 tentang Bank Indonesia pasal 1 ayat (10), "Kebijakan moneter adalah kebijakan yang ditetapkan dan dilaksanakan oleh Bank Indonesia untuk mencapai dan memelihara kestabilan nilai rupiah yang dilakukan antara lain melalui pengendalian jumlah uang beredar dan suku bunga". Kebijakan moneter memiliki target akhir yang ingin dicapai, yakni pertumbuhan ekonomi dan pemerataan pembangunan, kesempatan kerja, kestabilan harga, keseimbangan neraca pembayaran (Pohan, 2008: 26).

Untuk mencapai sasaran akhir ini, diperlukan adanya sasaran operasional agar proses transmisi dapat berjalan sesuai rencana. Kerangka operasional kebijakan moneter merupakan rangkaian langkahlangkah bank sentral dari penentuan dan prakiraan sasaran akhir, pemantauan variabel-variabel ekonomi yang dijadikan dasar perumusan kebijakan moneter hingga pelaksanaan pengendalian di pasar uang untuk mencapai sasaran akhir.

Mekanisme transmisi kebijakan moneter pada dasarnya menggambarkan bagaimana kebijakan moneter yang ditempuh bank sentral mempengaruhi berbagai aktivitas ekonomi dan keuangan sehingga pada akhirnya dapat mencapai tujuan akhir yang ditetapkan (Warjiyo dalam Hirawan, 2007). Pada dasarnya praktik pelaksanaan transmisi kebijakan moneter masing-masing negara berbeda antara satu negara dengan negara lainnya. Perbedaan ini disebabkan adanya perbedaan struktur perekonomian, perkembangan pasar keuangan dan sistem nilai tukar yang dianut oleh negara yang bersangkutan.

Inflasi merupakan salah satu varibel makro yang memiliki hubungan yang erat dengan kebijakan moneter, serta memiliki dampak yang besar terhadap perekonomian suatu negara, hal ini dikarenakan inflasi dapat mempengaruhi hampir segala aspek kegiatan ekonomi oleh karena itu diperlukan perhatian yang khusus.

Dalam ekonomi, inflasi memiliki pengertian suatu proses meningkatnya harga-harga secara umum dan secara terusmenerus (Nopirin,1987:25). Dapat juga dikatakan bahwa kenaikan harga barang yang hanya sementara tidak dapat diakatan sebagai sebuah penyebab terjadinya suatu inflasi. Literatur yang lain menyatakan bahwa inflasi merupakan "condition of continually rising price level so a nation is 
called face the inflation if inflation rate is extremely high for sustained period of time, its rate of money supply extremely high" (Mishkin,2004:632)

Pada dasarnya inflasi memiliki beberapa pengertian Mankiw (2006) menyatakan "Economist use the term inflation to describe a situation in which the economy's overall price level is rising". Oleh karena itu, dapat dikatakan bahwa kenaikan harga-harga barang tidaklah harus pada presentase yang sama tapi secara keseluruhan ada peningkatan pada level harga tertentu bahkan mungkin kenaikan harga pada kelompok barang dan jasa tersebut tidak terjadi secara bersamaan (Pohan,2008).

Diperlukan adanya suatu kebijakan yang bisa mengontrol tingkat inflasi yang terjadi dalam perekonomian sehingga efekefek negatif yang ditimbulkan oleh inflasi tidak menghambat pertumbuhan ekonomi suatu negara. Oleh sebab itu bank sentral harus membuat suatu kebjakan yang khusus mengatasi permasalahan inflasi, bank sentral pada beberapa negara telah menerapkan sebuah pemikiran terbaru dalam bidang kebijakan moneter yang disebut Inflation Targeting Framework (ITF).

\section{Inflation Targeting Framework}

(ITF) merupakan suatu kerangka kerja kebijakan moneter yang mempunyai ciri- ciri utama adanya pernyataan resmi dari bank sentral dan dikuatkan dengan undang-undang bahwa tujuan akhir dari kebijakan moneter adalah mencapai dan menjaga tingkat inflasi yang rendah, dan mengumumkan target inflasi kepada publik.

Pengumuman tersebut mengandung arti bahwa bank sentral memberikan komitmen dan jaminan kepada publik bahwa setiap kebijakannya selalu mengacu pada pencapaian target tersebut, dan bank sentral mempertanggung jawabkan kebijakannya apabila target tersebut tidak tercapai. Secara eksplisit dinyatakan bahwa inflasi yang rendah dan stabil merupakan tujuan utama dari kebijakan moneter.

Dalam penelitian ini ada beberapa variabel moneter yang biasa digunakan untuk mengkaji suatu kebijakan moneter. Variabel pertama yang digunakan adalah variabel suku bunga, dalam penelitian ini suku bunga yang digunakan adalah tingkat suku bunga yang digunakan sebagai acuan kebijakan moneter yaitu suku bunga Bank Indonesia untuk negara Indonesia.

Tingkat bunga memiliki peranan penting dalam suatu kebijakan moneter aktifitas menaikkan dan menurunkan tingkat suku bunga oleh otoritas moneter dapat mempengaruhi perekonomian. Menurut teori klasik, tabungan merupakan 
fungsi dari tingkat bunga, semakin tinggi tingkat bunga maka semakin tinggi pula keinginan masyarakat untuk menabung, dengan kata lain tingkat bunga yang tinggi masyarakat akan lebih terdorong untuk mengurangi pengeluaran untuk konsumsi guna menambah tabungannya. Tingkat suku bunga juga dapat digunakan oleh otoritas moneter dalam mempengaruhi jumlah uang beredar salah satu jenis uang beredar yang dapat dipengaruhi yaitu M2.

Variabel kedua yang digunakan dalam penelitian ini adalah variabel M2 yaitu Uang beredar adalah meliputi uang dalam peredaran, uang giral, dan uang kuasi. Uang kuasi terdiri dari deposito berjangka, tabungan, dan rekening (tabungan) valuta asing milik swasta domestik. seperti yang telah diketahui oleh masyarakat bahwa uang adalah alat yang digunakan untuk pembayaran barang dan jasa. Jenis uang beredar dalam masyarakat terdiri dari beberapa jenis yaitu M1, M2, dan M3, pemisahan dan klasifikasi tersebut bertujuan untuk mempermudah pengukuran total jumlah uang beredar dalam JUB.

Variabel ketiga yang digunakan dalam penelitian ini adalah tingkat inflasi yang diukur dalam IHK atau indeks harga konsumen, variabel ini sangat penting digunakan untuk mengukur tingkat inflasi suatu negara pada waktu tertentu, beberapa pendekatan lain yang digunakan untuk mengukur tingkat harga adalah dengan menggunakan perubahan indeks harga perdagangan besar (IHPB), IHPB sama halnya dengan IHK tapi dalam IHPB dipisahkan berdasarkan sektor-sektor ekonomi, ekspor dan impor, baik secara total keseluruhan maupun tanpa migas.

Variabel yang terakhir yang digunakan dalam penelitian ini adalah nilai tukar (exchange rate). Nilai tukar atau kurs didefinisikan sebagai nilai suatu mata uang terhadap mata uang lain (Mishkin, 2008). Sementara itu Krugman (2000) menjelaskan nilai tukar sebagai harga sebuah mata uang yang diukur atau dinyatakan dalam mata uang lain.

\section{METODOLOGI PENELITIAN}

Metode yang digunakan pada penelitian ini adalah metode Vector Error Correction Model (VECM). VECM merupakan bentuk VAR yang terestriksi. Restriksi tambahan ini harus diberikan karena keberadaan bentuk data yang tidak stasioner namun terkointegrasi. VECM kemudian memanfaatkan informasi restriksi kointegrasi tersebut kedalam spesifikasinya. Karena itulah VECM sering disebut sebagai desain VAR bagi series nonstasioner yang memiliki hubungan kointegrasi. 
VECM merupakan model non struktural dalam analisis ekonometrika yang dapat digunakan untuk mengetahui hubungan suatu variabel terhadap jangka panjangnya akibat adanya shocks yang permanen. Pada dasarnya Analisis VECM bisa disamakan dengan suatu model persamaan simultan, oleh karena dalam analisis VECM kita mempertimbangkan beberapa variabel endogen secara bersama-sama dalam suatu model. Perbedaannya dengan model persamaan simultan biasa adalah bahwa dalam Analisis VECM masing-masing variabel selain diterangkan oleh nilainya di masa lampau, juga dipengaruhi oleh nilai masa lalu dari semua variabel endogen lainnya dalam model yang diamati. Di samping itu, dalam analisis VECM biasanya tidak ada variabel eksogen.

Uji stasioneritas data digunakan untuk mengidentifikasi apakah suatu data stasioner atau tidak. Uji stasioner sangatlah diperlukan dalam pengujian yang menggunakan data time series, Apabila data time series tidak stasioner akan mengakibatkan terjadinya regresi lancung atau sporious regression yang berarti regresi tersebut adalah palsu dan tidak dapat diestimasi, implikasi dari permasalahan tersebut menyebabkan hasil regresi yang dihasilkan tidak memiliki arti secara ekonomi. (Widarjono, 2005: 365).
Data time series dikatakan stasioner jika data tersebut tidak mengandung akar unit (unit root) dimana mean, variance dan covariance konstan sepanjang waktu. Sebaliknya apabila data time series tidak stasioner maka mengandung akar-akar unit, dimana mean, variance dan covariance tersebut tidak konstan. (Thomas, 1997:374)

Uji stastioneritas data dapat dilakukan dengan menggunakan Augmented Dickey-Fuller (ADF) pada derajat yang sama (level atau different) hingga memperoleh data yang stasioner, yaitu data yang variansnya tidak terlalu besar dan mempunyai kecenderungan mendekati nilai rata-ratanya (Enders: 1995).

Salah satu yang paling penting dalam uji stasioneritas adalah penentuan lag optimal. Harris (1995:65) menjelaskan bahwa jika lag yang digunakan dalam uji stasioneritas terlalu sedikit, maka residual dari regresi tidak akan menampilkan proses white noise sehingga model tidak dapat mengestimasi actual error secara tepat. Dalam menentukan lag optimal kita pilih kriteria yang memiliki final prediction error correction (FPE) yang merupakan penjumlahan dari AIC, SIC, dan HQ yang paling kecil dari semua lag yang diajukan. 
Langkah selanjutnya dalam mengestimasi persamaan VECM adalah melakukan uji kointegrasi. Konsep kointegrasi adalah kerangka formal untuk menguji dan mengestimasi hubungan jangka panjang di antara variabel ekonomi yang diteliti. Kointegrasi merupakan kombinasi hubungan linear dari variabelvariabel yang nonstasioner dan semua variabel tersebut harus terintegrasi pada orde atau derajat yang sama Uji kointegrasi merupakan kelanjutan dari uji stasioneritas dan derajat integrasi. Pada saat dilakukan uji stasioneritas, apabila suatu variabel tidak stasioner dalam tingkat level, maka harus dilakukan uji integrasi.

Dalam penelitian ini, pengujian kointegrasi menggunakan metode Johansen's Multivariate Cointegration Test. Prosedur pengujian residual ini hampir sama dengan pengujian stasioneritas pada variabel-variabel dalam model. Hasil estimasi nilai statistik ADF kemudian dibandingkan dengan nilai kritisnya. Jika nilai statistiknya lebih besar dari nilai kritisnya, maka variabel-variabel yang diamati saling berkointegrasi atau mempunyai hubungan jangka panjang. Sebaliknya, apabila nilai statistiknya lebih kecil dari nilai kritisnya, maka variabel yang diamati tidak terkointegrasi dan tidak memiliki hubungan jangka panjang.
Untuk mengetahui pengaruh shock dalam perekonomian maka digunakan metode impulse respon function. Sims (1980) menjelaskan bahwa fungsi impulse respon menggambarkan ekspektasi $k$ periode ke depan dari kesalahan prediksi suatu variabel akibat inovasi dari variabel yang lain. Sehingga dapat dilihat lamanya pengaruh dari shock suatu variabel terhadap variabel lain sampai pengaruhnya hilang atau kembali ke titik keseimbangan.

Variance Decompositions atau disebut juga forecast error variance decomposition merupakan perangkat pada model VAR/VECM yang akan memisahkan variasi dari sejumlah variabel yang diestimasi menjadi komponenkomponen shock atau menjadi variabel innovation, dengan asumsi bahwa variabel-variabel innovation tidak saling berkorelasi. Kemudian, variance decomposition akan memberikan informasi mengenai proporsi dari pergerakan pengaruh shock pada sebuah variabel terhadap shock variabel yang lain pada periode ini dan periode yang akan datang.

\section{PEMBAHASAN}

$$
\begin{aligned}
& \text { Berdasarkan hasil } \begin{array}{r}
\text { penelitian } \\
\text { impulse response dan variance }
\end{array} \\
& \text { decomposition di Indonesia sebelum dan } \\
& \text { sesudah penerapan inflation targeting }
\end{aligned}
$$


framework maka dapat diketahui bahwa masing-masing nilai tukar (ER), tingkat suku bunga (IR) dan variabel jumlah uang beredar (M2) memiliki hubungan terhadap tingkat inflasi ini dapat dilihat dari adanya respon inflasi terhadap perubahan shock masing-masing variabel tersebut.

Pada variabel pertama nilai tukar (ER) respon inflasi sebelum penerapan inflation targeting framework (ITF) ). Pada awal periode, adanya shock pada ER direspon positif oleh inflasi hingga periode ketiga, yaitu mencapai titik tertinggi. Setelah periode keempat mulai bergerak turun hingga periode kelima dan selanjutnya kembali mengalami kenaikan kembali hingga periode kedelapan sedangkan kontribusi shock cenderung mengalami penurunan hingga periode kesepuluh hingga mencapai $42.62536 \%$.

Selanjutnya respon inflasi pada nilai tukar (ER) sesudah penerapan inflation targeting framework (ITF). Pada awal periode, adanya shock pada ER direspon positif oleh inflasi hingga periode kedua, yaitu mencapai titik tertinggi. Setelah periode keempat respon inflasi mulai bergerak menghimpit garis keseimbangan sedangkan kontribusi shock cenderung mengalami fluktuasi hingga pada periode kesepuluh mencapai $4.441346 \%$.
Pada variabel kedua yaitu tingkat suku bunga (IR) respon inflasi sebelum penerapan inflation targeting framework (ITF). Pada periode awal hingga periode ketiga respon inflasi masih mengalami fluktuasi dan mengalami peningkatan pada periode keempat dan selanjutnya terjadi penurunan respon inflasi sampai periode kesepuluh sedangkan kontribusi shock cenderung mengalami fluktuasi hingga pada periode kesepuluh mencapai $9.787261 \%$.

Selanjutnya respon inflasi pada tingkat suku bunga (IR) sesudah penerapan inflation targeting framework (ITF). Pada periode awal sampai periode kedua shock pada IR direspon positif, pada periode ketiga terjadi penurunan sehingga kenaikan satu persen tingkat bunga direspon dengan penurunan inflasi sedangkan kontribusi shock terus mengalami peningkatan hingga mencapai $10.39968 \%$ pada periode kesepuluh.

Pada variabel yang terakhir yaitu jumlah uang beredar (M2) respon inflasi sebelum penerapan inflation targeting framework (ITF). Pada periode pertama sampai periode kedua terjadi penurunan dan mengalami peningkatan pada periode ketiga hingga keempat dan selanjutnya mengalami penurunan pada periode kelima dan selanjutnya inflasi direspon positif pada periode terakhir sedangkan kontribusi 
shock cenderung mengalami peningkatan hingga mencapai $10.24901 \%$ pada periode kesepuluh.

Selanjutnya respon inflasi pada tingkat suku bunga (IR) sesudah penerapan inflation targeting framework (ITF). Pada periode pertama sampai periode kedua terjadi penurunan dan mengalami peningkatan pada periode ketiga hingga keempat danselanjutnya respon inflasi mengalami peningkatan dan bergerak menghimpit garis keseimbangan hingga periode ke sepuluh sedangkan kontribusi shock cenderung mengalami peningkatan hingga mencapai $4.118642 \%$ pada periode terakhir.

Hasil penelitian pada masingmasing variabel menunjukkan bahwa ada perbedaan hubungan masing-masing variabel nilai tukar, tingkat suku bunga dan jumlah uang beredar terhadap inflasi sebelum dan sesudah penerapan inflation targeting sehingga dalam menetapkan suatu kebijakan di Indonesia maka perlu mempertimbangkan pengaruh shock pada variabel-variabel dalam mempengaruhi target inflasi yang akan berpengaruh pada pertumbuhan ekonomi Indonesia.

Dari tahun 1990 hingga tahun 1996, pertumbuhan Produk Domestik bruto (PDB) Indonesia mengalami kenaikan dan penurunan yang tidak begitu besar perbedaannya. Sampai lah pada tahun 1997 perekonomian Indonesia mengalami kemerosotan akibat kriris yang berkepanjangan. Sehingga pada tahun 1998, pertumbuhan perekonomian Indonesia mengalami penurunan drastis yaitu sebesar $-13,13 \%$. Dengan jumlah suku bunga yang jauh melambung tinggi. Saat tahun 1996 suku bunga hanya bekisar 12,8\% lalu naik pada tahun 1997 sebesar $20 \%$, dan memuncak pada tahun 1998 sebesar $35,52 \%$.

Pada saat itu pemerintah Indonesia mengalami krisis yang sulit, saat krisis tingkat inflasi di Indonesia meningkat tajam, dan pernah mencapai 82,40 persen pada September 1998. Tingkat inflasi yang tinggi pada saat itu mencerminkan ketidakstabilan harga, hal ini tentu saja mengurangi daya beli masyarakat. Ketika inflasi terjadi jumlah uang yang beredar meningkat hal ini akan berdampak pada terdepresiasinya nilai tukar.

Nilai tukar Rupiah selalu mengalami fluktuasi dari tahun ke tahun, pada saat sebelum krisis yaitu dari tahun 1993-1996, nilai tukar Rupiah berada pada kisaran 2.110-2.383 Rupiah per US Dollar. Ketika terjadi krisis ekonomi yang melanda kawasan Asia pada pertengahan 1997 perekonomian Indonesia terkena dampak negatifnya. Krisis mata uang yang melanda Indonesia ditandai dengan 
melemahnya mata uang Rupiah terhadap Dollar pada pertengahan tahun 1997.

Rupiah yang bernilai 2.450 Rupiah per US Dollar pada bulan Juni 1997 mengalami depresiasi secara terus menerus hingga pada akhir tahun 1997 mencapai 4.650 Rupiah per US Dollar Untuk menahan laju nilai tukar Rupiah, pada tanggal 14 Agustus 1997 pemerintah melepas sistem kurs mengambang terkendali (managed floating system) dan menerapkan sistem kurs mengambang bebas (free floating system). Namun memasuki tahun 1998 kondisi nilai tukar Rupiah semakin parah dan puncaknya mencapai 14.850 Rupiah per US Dollar pada Juni 1998.

Langkah kebijakan yang diambil selama krisis ini terfokus kepada mengembalikan kestabilan makroekonomi dan membangun kembali infrastruktur ekonomi, khususnya di sektor perbankan dan dunia usaha. di bidang moneter, ditempuh kebijakan moneter ketat untuk mengurangi laju inflasi dan penurunan atau depresiasi nilai mata uang.

Penerapan kerangka kebijakan moneter tersebut didasarkan pada pengendalian jumlah uang beredar. Di dalam kerangka tersebut Bank Indonesia berupaya mengendalikan uang primer sebagai sasaran operasional kebijakan moneter. Dengan menggunakan kerangka kebijakan moneter tersebut, Bank Indonesia pada periode awal krisis ekonomi, terutama selama tahun 1998, menerapkan kebijakan moneter ketat untuk mengembalikan stabilitas moneter.

Kebijakan moneter ketat tersebut tercermin pada pertumbuhan tahunan sasaran indikatif uang beredar yang terus ditekan dari level tertinggi 30,13\% pada tahun 2000 menjadi $9,58 \%$ pada tahun 2001. Kebijakan moneter ketat terpaksa dilakukan karena dalam periode itu ekspektasi inflasi di tengah masyarakat sangat tinggi dan jumlah uang beredar meningkat sangat pesat.

Di tengah tingginya ekspektasi inflasi dan tingkat risiko memegang rupiah, upaya memperlambat laju pertumbuhan uang beredar telah mendorong kenaikan suku bunga domestik secara tajam. Suku bunga yang tinggi diperlukan agar masyarakat mau memegang rupiah dan tidak membelanjakannya untuk hal-hal yang tidak mendesak serta tidak menggunakannya untuk membeli valuta asing..

Suku bunga SBI bulan yang selama ini menjadi patokan (benchmark) bagi bank-bank terus menurun dari level tertinggi 35,52\% pada tahun 1998 menjadi 7,43\% pada akhir April 2004.Penurunan suku bunga SBI yang cukup tajam itu 
diikuti oleh suku bunga pasar uang antarbank (PUAB) dan simpanan perbankan dengan laju penurunan yang hampir sama.

Suku bunga kredit (kredit modal kerja) pun mengalami penurunan meskipun tidak secepat dan sebesar penurunan suku bunga simpanan perbankan. Penurunan laju inflasi, penguatan nilai tukar rupiah, dan penurunan suku bunga membentuk suatu lingkaran yang saling memperkuat sehingga membuka peluang bagi pemulihan ekonomi.

Sejak tahun 2000, dengan diberlakukannya UU No. 23 Tahun 1999 BI telah menentukan dan mengumumkan sasaran inflasi sebagai sasaran akhir kebijakan moneter. Dengan amandemen UU Bank Indonesia No. 3 Tahun 2004, Pemerintah setelah berkoordinasi dengan Bank Indonesia telah menetapkan dan mengumumkan sasaran inflasi IHK untuk tahun 2005, 2006, dan 2007. BI telah menempuh sejumlah langkah dalam memperkuat persyaratan untuk penerapan Inflation Targeting Framework (ITF).

Pada dua tahun pertama penerapan inflation targeting, target inflasi yang ditetapkan belum berhasil tercapai dengan baik. Pada tahun 2000 dan 2001 inflasi aktual sebesar $9.35 \%$ dan $12.55 \%$ berada diatas kisaran target yaitu sebesar 5-7\%.
Pada Tahun 2002 inflasi berada tidak jauh dari kisaran target inflasi sebesar 9-10\%, terjadinya penurunan inflasi dari dua tahun sebelumnya disebabkan menguatnya nilai rupiah. Namun kebijakan harga dan pendapatan yang dilakukan pemerintah tetap mengakibatkan terjadinya inflasi sehingga mengakibatkan inflasi aktual masih berada pada tingkat yang tinggi.

Pada tahun 2003 inflasi aktual Indonesia sebesar 5\% berada dibawah target yang ditetapkan yaitu sebesar 810\%. Hal ini dikarenakan semakin menguatnya nilai rupiah dan menurunnya tingkat inflasi akibat kebijakan harga dan pendapatan yang dilakukan pemerintah. Akhirnya pada tahun 2004 Indonesia berhasil mencapai target yang ditatapkan yaitu sebesar 4,5\%-6,5\% dengan inflasi aktual sebesar $6,4 \%$.

Inflasi 2005 mencapai 17,11 persen, jauh di atas inflasi tahun 2004 yang mencapai 6,4\% inflasi tahun 2005 merupakan inflasi tertinggi sejak pasca krisis. Tingginya laju inflasi disebabkan kenaikan administered price khususnya harga BBM pada bulan Maret dan Oktober 2005 dan administered prices lainnya seperti tarif angkutan, elpiji, cukai rokok, dan tarif tol. Inflasi administered prices hingga Desember 2005 tercatat sebesar 42,01 persen year on year (yoy). Laju inflasi juga disebabkan adanya gangguan 
pasokan dan distribusi sehingga menyebabkan tingginya harga bahan makanan (volatile foods) sebesar 15,18 persen, adanya peningkatan ekpektasi inflasi yang didorong oleh kenaikan harga BBM dan pelemahan nilai tukar Rupiah (Sitorus 2006).

Ketidakstabilan mata uang Rupiah mulai terjadi sejak bulan Januari 2004. Sejak bulan itu Rupiah terdepresiasi tidak hanya dengan mata uang Dollar, tetapi juga dengan mata uang Euro dan Yen. Ini mengindikasikan pengaruh internal lebih menentukan dibandingkan dengan pengaruh eksternal. Dengan kata lain kondisi Indonesialah yang membuat mata uang Rupiah menjadi melemah.

Ketika Bank Indonesia merespon dengan meningkatkan suku bunga dalam negeri untuk disesuaikan dengan suku bunga internasional, langkah penyesuaian yang diambil sudah terlambat. Terjadinya peningkatan suku bunga domestik merupakan respon atas meningkatnya suku bunga internasional yang mengalami pembalikan trend sejak the Fed menaikkan suku bunganya di pertengahan 2004. Kenaikan suku bunga SBI, segera akan diikuti oleh kenaikan suku bunga simpanan dan kredit. Kenaikan yang terlalu cepat ini tentu akan menyulitkan perbankan dan sektor riil (Sugema, et al., 2006).
Sedangkan pada tahun 2006 inflasi aktual mengalami penurunan menjadi sebesar $6.6 \%$ hal ini dikarenakan kebijakan moneter yang diterapkan Bank Indonesia mampu menahan ekspektasi inflasi masyarakat sehingga perekonomian menjadi lebih baik.. Pada tahun 2007 inflasi dapat sesuai target yaitu sebesar $6.59 \%$ dengan target yang ditetapkan adalah sebesar 6-7\%.

Adanya krisis global pada tahun 2008 menjadi suatu tantangan yang berat bagi perekonomian Indonesia hal ini mengakibatkan tingkat inflasi kembali naik menjadi sebesar $11.06 \%$ barada diatas target yang ditetapkan yaitu sebesar 5-6\% hal ini memperlihatkan bahwa kondisi eksternal belum menunjukkan kondisi yang kondusif, seperti adanya kecenderungan kenaikan suku bunga internasional, kenaikan harga minyak dunia, dan masih tingginya inflasi dunia. Kondisi-kondisi tersebut tentu saja harus dipertimbangkan dalam menentukan kebijakan untuk memperbaiki kondisi perekonomian.tetapi tingkat pertumbuhan sebesar 5\% menandakan Indonesia tidak terlalu berpengaruh terhadap krisis global (Adiputra,2009).

Sedangkan pada tahun 2009 inflasi mengalami penurunan menjadi sebesar $2.78 \%$ dibawah target yang ditetapkan yaitu sebesar 4,5\%-5,5\% dan kemudian 
pada tahun 2010 terjadinya peningkatan ekspektasi masyarakat mengakibatkan tingkat inflasi naik menjadi $6.96 \%$ sedikit berada diatas target yang ditetapkan Bank Indonesia yaitu sebesar 5-6\%.

Bagi masyarakat secara umum, kestabilan harga merupakan sesuatu yang sangat penting khususnya bagi golongan masyarakat berpendapatan tetap karena sangat berpengaruh pada penurunan daya beli masyarakat. Bagi kalangan dunia usaha, inflasi yang tinggi akan sangat menyulitkan kalkulasi perencanaan bisnis dan dengan demikian akan berdampak buruk bagi aktivitas perekonomian dalam jangka panjang. Bagi banyak ekonom, telah terbentuk semacam kesepakatan bahwa inflasi yang tinggi akan berdampak buruk bagi proses pertumbuhan ekonomi dalam jangka panjang.

\section{KESIMPULAN}

Berdasarkan uraian dari bab sebelumnya dan analisis dengan menggunakan data empiris yang telah dilakukan, maka dapat ditarik kesimpulan untuk menjawab permasalahan sebagai berikut :

1. Penelitian ini melihat bagaimana hubungan antara masing-masing variabel tingkat suku bunga, jumlah uang beredar (M2), dan nilai tukar terhadap inflasi di Indonesia sebelum dan sesudah penerapan ITF, maka dapat diketahui bahwa masing-masing nilai tukar (ER), tingkat suku bunga (IR) dan variabel jumlah uang beredar (M2) memiliki hubungan terhadap tingkat inflasi ini dapat dilihat dari adanya respon inflasi terhadap perubahan shock masing-masing variabel tersebut.

2. Adanya respon yang berbeda oleh inflasi terhadap masing-masing variabel sebelum dan sesudah penerapan ITF dimana respon terhadap nilai tukar cenderung positif sebelum penerapan ITF dan memiliki kontribusi shock yang besar berbeda dengan sesudah penerapan ITF dimana kontribusi shock terhadap inflasi jauh lebih kecil,selanjutnya pada variabel tingkat suku bunga respon inflasi 
cenderung berfluktuasi sebelum

penerapan ITF dan cenderung

negatif setelah penerapan ITF dan

kontribusi shock terhadap inflasi

jauh lebih besar dibandingkan

dengan variabel yang

lain,sedangkan untuk variabel

jumlah uang beredar (M2) respon

inflasi cenderung positif pada

periode sebelum dan sesudah

penerapan ITF tetapi kontribusi

shock jauh lebih kecil

dibandingkan pada periode

sebelum penerapan ITF.

3. Berdasarkan uji kointegrasi tingkat inflasi (INF), nilai tukar (ER), suku bunga (IR), jumlah uang beredar

$$
\text { memiliki hubungan }
$$

kointegrasi sehingga masing

masing variabel dalam setiap

jangka pendek cenderung saling

berhubungan dan saling

menyesuaikan untuk mencapai

keseimbangan masing-masing

dalam jangka panjang.
Berdasarkan seluruh hasil tersebut maka dapat dilihat bahwa penerapan ITF di Indonesia telah menyebabkan perubahan pada respon kebijakan moneter di Indonesia, hal ini dikarenakan adanya mekanisme transmisi kebijakan moneter yang menggambarkan tindakan bank Indonesia melalui perubahan-perubahan instrumen dan target operasionalnya mempengaruhi berbagai variabel moneter sebelum akhirnya berpengaruh pada tujuan akhir yaitu inflasi, Untuk mencapai tujuan itu Bank Indonesia menetapkan suku bunga kebijakan BI Rate sebagai instrumen kebijakan utama untuk mempengaruhi aktivitas kegiatan perekonomian sehingga dapat dilihat bahwa pada periode penerapan ITF tingkat suku bunga memiliki kontribusi shock yang lebih besar dibandingkan variabel yang lain

Dari temuan penelitian juga dapat disimpulkan bahwa penerapan ITF di Indonesia lebih bersifat diskresi daripada sebuah rule dalam menentukan suku bunga 
acuan, hal tersebut ditunjukkan dengan parameter respon inflasi yang berfluktuasi sepanjang periode penerapan ITF. Sementara apabila dilakukan pendekatan yang lebih bersifat rule maka akan menghasilkan sebuah target acuan yang konstan dari waktu ke waktu.

Penerapan kebijakan Inflation

Targeting Framework dalam mekanisme transmisi kebijakan moneter di Indonesia berdasarkan penelitian ini terbukti efektif dan efisien dalam jangka panjang. Fenomena ini dapat dijelaskan, karena selama periode penelitian fungsi intermediasi perbankan masih belum pulih sehingga perlu waktu yang lebih lama untuk mempengaruhi ekspektasi inflasi masyarakat.

\section{DAFTAR PUSTAKA}

Bank Indonesia, 2008. Indonesia Financial Statistic. BI. Jakarta.

Sims, C.1980. Macroeconomics and reality. Econometrica. Vol 48.1980.pp: 1-48

Harris, Richard (1995), Cointegration Analysis in Econometric Modeling. Prentice Hall. New York.

Hebbel, Klauss Schmidt, and Matias Tapia (2002). Inflation Trageting In Chile. North American Journal Of Economics And Finance. Vol.13 : 125-146

Hubbard, R. Glenn, 2002. Economic Growth And Reform: Lessons From The United States And Japan. EIJS Working Paper Series 163. The European Institute of Japanese Studies, revised 12 Jan 2004.

Civcir irfan, Anıl Akc,a glayan (2010). Inflation targeting and the exchange rate: Does it matter in Turkey? Journal of Policy Modeling 32 (2010) 339-354.

Lin, Shu \& Ye, Haichun, 2009. Does inflation targeting make a difference in developing countries?.Journal of Development Economics, Elsevier, vol. 89(1), pages 118-123, May.

Mankiw. 2006. Macroeconomics. $6^{\text {th }}$ Edition. Adison Avenue. New York.

Mc Eachern, William. 2000. Ekonomi Makro. Terjemahan. Jakarta: Salemba Empat

Pohan, Aulia. 2008. Kerangka Kebijakan Moneter Dan Implementasinya Di Indonesia. Jakarta: PT. Raja Grafindo Persada. 
Thomas, Lloyd B.1997. Money, Banking, and Financial Markets. New York: McGraw-Hill. Warjiyo \& Solikin 2004. Kebijakan Moneter di Indonesia. Jakarta: PPSK BI.

Widarjono, Agus. 2005. Ekonometrika: Teori Dan Aplikasi Untuk Ekonomi Dan Bisnis, Yogyakarta: Penerbit Ekonisia Fak.Ekonomi UII. 